\title{
Effect of arbuscular mycorrhizal (AM) fungi inoculation on enzymatic activity and zinc uptake under direct seeded rice system
}

\author{
Ranjeet Kumar and Mahendra Singh* \\ Department of Soil Science and Agricultural Chemistry, BAU, Sabour-813210, Bhagalpur (Bihar), INDIA \\ *Corresponding author. E-mail: mahendra_saini_soil@yahoo.com \\ Received: August 18, 2016; Revised received: February 21, 2017; Accepted: May 20, 2017
}

\begin{abstract}
The application of treatment $\mathrm{T}_{3}$ (Glomus mosseae $+100 \%$ RDF NK) produced significantly more root volume by $72.60 \%, 17.80 \%, 12.25 \%, 14.13 \%$ over the application of treatment $\mathrm{T}_{1}$ (Control), treatment $\mathrm{T}_{5}$ (Glomus coronatum+ $100 \%$ RDF NK), $\mathrm{T}_{6}$ (Gigasporadecipein + $100 \%$ RDF NK) and T 7 (BAU AM-1(Glomus sp + $100 \%$ RDF NK), respectively. Similar trend shows at harvesting stage, here the maximum root volume (23c.c) was recorded by the application of $\mathrm{T}_{3}$ (Glomus mosseae $+100 \%$ RDF NK). Maximum AM colonization and spore count was observed at panicle initiation stage with the application of treatment $\mathrm{T}_{3}$ (Glomus mosseae $+100 \%$ RDF NK). This treatment also gave maximum dehydrogenase activity $\left(55.86 \mu \mathrm{g} \mathrm{TPF} \mathrm{g} \mathrm{g}^{-1} 24 \mathrm{hr}^{-1}\right)$, acid phosphatase activity $(0.299$ $\mathrm{mg}$ PNP g $\left.\mathrm{gr}^{-1}\right)$ and alkaline phosphatase activity $\left(0.54 \mathrm{mg} \mathrm{PNP} \mathrm{g}^{-1} \mathrm{hr}^{-1}\right)$ at panicle initiation stage. Application of treatment $\mathrm{T}_{3}$ (Glomus mosseae $+100 \%$ RDF NK) significantly increased DTPA extractable $\mathrm{Zn}$ in soil and $\mathrm{Zn}$ content in plant when compared with all the treatments except treatment $\mathrm{T}_{6}$ (Gigasporadecipien+100\% RDF NK). The maximum zinc uptake $\left(0.056 \mathrm{mg} \mathrm{pot}^{-1}\right.$ ) by grain was recorded under treatment $\mathrm{T}_{3}$ (Glomus mosseae $+100 \%$ RDF NK) followed by application of treatment $\mathrm{T}_{6}$ (Gigasporadecipien $+100 \% \mathrm{~N}$ and K). Highest grain yield (14.08 g pot:-1) was found with the treatment $\mathrm{T}_{3}$ (Glomus mosseae $+100 \%$ RDF NK). As evident from the results, the AM fungal inoculation can effectively modify the soil microbe population and community structure by increasing the soil enzymatic activities and significantly increased the zinc uptake by grain in direct seeded rice (DSR).
\end{abstract}

Keywords: DSR, Mycorrhiza, Rice yield, Soil enzyme, Spore count, Zinc uptake

\section{INTRODUCTION}

In dry direct seeded rice (DSR), because of the aerobic condition and alternate wetting/drying cycles, the plant availability of several major nutrients including $\mathrm{N}$ and micronutrients like $\mathrm{Zn}$ and $\mathrm{Fe}$ is likely to be less. Due to poor native bioavailable $\mathrm{Zn}$ and low exogenous supply, depletion zones are formed around roots. In plants, $\mathrm{Zn}$ plays an significant role as integral co-factor of over 300 enzymes which are involved in biosyntheses and turnovers of proteins, nucleic acids, carbohydrates, and lipids. $\mathrm{Zn}$ deficiency causes a lot of health problems in humans, such as impairments of physical development, immune system, and brain function (Cakmak, 2008). In addition, $\mathrm{Zn}$ is critical for the synthesis of phytohormones such as auxin, absicic acid, gibberellins and cytokinins. Thus, its deficiency in plant tissues adversely affects various vital processes occurring within plant body. Although $\mathrm{Zn}$ is required by the plant in microconcentration, its bioavailable fraction in soil is very low. Its deficiency is a widely occurring constraint for rice production and for human nutrition. To improve zinc uptake by plants, it should be brought in close proximity of roots. This can be achieved either by external application of $\mathrm{Zn}$ or by improving the growth and surface area of roots thus enabling them to absorb nutrients beyond the depletion zone. Rhizosphere microflora especially mycorrhizal fungus is widely known for its impact on root architecture. Mycorrhizal plants take up $\mathrm{Zn}$ over longer distances crossing the depletion zone. Lehman et al. (2014) confirmed by a meta-analysis that AMF positively affects $\mathrm{Zn}$ concentrations in various crop plant tissues including rice. Hajiboland et al. (2009) studied the influence of AMF on the uptake of $\mathrm{Zn}$ and $\mathrm{P}$ by two contrasting rice genotypes in a pot experiment. After inoculation with mycorrhiza they observed up to two-fold higher $\mathrm{Zn}$ uptake by rice genotypes under $\mathrm{Zn}$ deficiency. An enhanced AMF inoculation under aerobic condition has been shown to increase rice $\mathrm{Zn}$ uptake as observed by Gao et al. (2007). They observed that AMF inoculated plants produced more biomass and took up more $\mathrm{Zn}$ than the non-mycorrhizal control. Soil enzymatic activities regulate the various indices of soil fertility, soil productivity and soil quality (Busto and Perez-Mateos, 1997). AM fungi can increase soil enzyme activities, such as phosphatase (Mar Vazquez et al., 2000), dehydrogenase, urease, protease and $\beta$ glucosidase (Caravaca et al., 2004). Mar Vazquez et al. (2000) reported mycorrhizal colonization induced qualitative changes in the microbial population and enzyme activities in the rhizosphere of maize plants. 
On the other hand, soil phosphatase and urease are closely related to the $\mathrm{P}$ and $\mathrm{N}$ nutrition of plants. Thus, the enhancement of soil enzyme activities is one of the physiological and biochemical mechanisms involved in a mycorrhization effect on plant mineral nutrition. Considering with these facts the present investigation has been formulated to evaluate the role of vesicular arbuscular mycorrhizal fungi on the bioavailability of $\mathrm{Zn}$ in Direct Seeded rice grain. The present investigation was undertaken with an objective to determine the effect of AM inoculation on root volume, soil enzymatic activity and zinc uptake by grain under low soil phosphorous and zinc conditions typical of the direct seeded rice eco-system.

\section{MATERIALS AND METHODS}

The present study was undertaken to screen the AM fungi for direct seeded rice crop during the kharif season of 2015-16 with a promising variety ShushkSamrat, at Bihar Agricultural University, Sabour, Bhagalpur, India. Inoculums of the five AM species viz., Glomus mosseae, Glomus coronatum,Glomus intraradices Gigasporadecipien and were commercial products of The Energy Resource Institute (TERI), New Delhi, India. The products consisted of fragments of colonized roots and spores of AM fungi in a vermiculite substrate. One Local (BAU AM-1 (Glomus sp.) was taken from Department of Soil Science and Agricultural Chemistry, BAU, Sabour. The field soil $(0-15 \mathrm{~cm})$ used for the pot experiment was loamy sand in texture, having a $\mathrm{pH}$ of 7.8 and $\mathrm{EC}$ of $0.20 \mathrm{dS} \mathrm{m}^{-1}$. The organic carbon content of the substrate was $0.47 \%$, and the available nitrogen, phosphorus and potassium content was found 125.44, 12.55 and $240.92 \mathrm{~kg} \mathrm{ha}^{-1}$, respectively. Among micronutrient zinc content was $0.48 \mathrm{ppm}$.

Seeds were surface-sterilized by treatment with a $1: 1$ mixture of $\mathrm{H}_{2} \mathrm{O}_{2}$ and absolute ethanol for 2 minutes

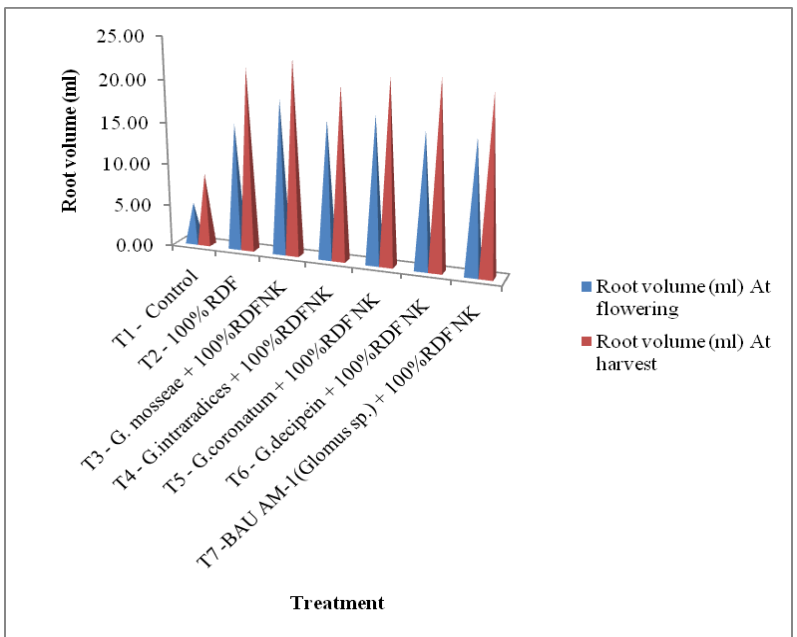

Fig. 1. Effect of AM fungi species on root volume (cc) of $D S R$. followed by a treatment with $0.05 \% \mathrm{HgCl}_{2}$ for $1 \mathrm{mi}$ nute. The sterilizing agents were drained aseptically, and the seeds were washed for 10-12 times in sterile distilled water to remove all traces of the chemicals. Earthen pots of $15 \mathrm{~cm}$ height and $30 \mathrm{~cm}$ diameter were filled with $15 \mathrm{~kg}$ of sterilized substrate. The following treatment structure was formulated for the study: $\mathrm{T}_{1}$ control, $\mathrm{T}_{2}$ - RDF (100\%), $\mathrm{T}_{23}$ G. mosseae $+100 \%$ RDFNK, $\mathrm{T}_{4^{-}}$G. coronatum $+100 \%$ RDFNK, $\mathrm{T}_{5^{-}} G$. intraradices $+100 \%$ RDFNK, $\mathrm{T}_{6^{-}}$G. decipiens +100 $\%$ RDFNK and $\mathrm{T}_{7-}$ Local (BAU AM-1 (Glomus sp.) + $100 \%$ RDFNK. About $5 \mathrm{~g}$ of the AM inoculum source (containing and 10 spores $\mathrm{g}^{-1}$ ) was mixed with the upper $4 \mathrm{~cm}$ of the substrate in each pot. In each pot, 5 sterile seeds of rice were planted. The one third dose of nitrogen and full dose of phosphorous and potassium were applied at the time of sowing and remaining two third dose of nitrogen were applied at the tilering and panicle initiation stage. Irrigation was applied as per crop requirement. Five plants were up rooted from each pot by destructive sampling at harvesting stage and measure the root volume by volume displacement method provides (Harrington et. al., 1994).

Samples of roots of the plants with adhering soil were collected at 75 days after sowing (DAS). They were washed repeatedly with sterilized distilled water and fragmented into small segments of $1 \mathrm{~cm}$. The root segments were cleared in $10 \% \mathrm{KOH}$, followed by acidification for a few minutes using $\mathrm{HCl}(2 \%)$. Staining was done using trypan blue $(0.05 \% \mathrm{w} / \mathrm{v})$ in lactoglycerol, which is a mixture of lactic acid, glycerol and distilled water 1:1:1. The root colonization observed by the method given by Philips and Hayman (1970). The percent root colonization was calculated by using following formula:

$\%$ of mycorrhizal colonization $(\%)=$

Number of root segment examine $\times 100$

Total Number of root segment taken



Fig. 2. Effect of various AM fungi on dehydrogenase activity ( $\mu \mathrm{g} \mathrm{TPF} \mathrm{g}^{-1} 24 \mathrm{hr}^{-1}$ ). 
The soil sample collected from the each pot along with plant roots. Soil sample were soaked for 30 minutes using about $400 \mathrm{~mL}$ of $2 \%$ (w/v) "Calgon" (Nahexametaphosphate) solution before being homogeneously mixed manually. Samples were mixed for 10 minutes, then the soil solution was allowed to settle for about 20 seconds before the supernatant was decanted carefully onto a series of sieves. The remaining soil was then mixed again with tap water, stirred for 5 minutes, settled for about 20 seconds, then decanted onto the sieve set. This process was repeated until the solution looked clear. There were different sieve sets used. However, the top one was a $750 \mu \mathrm{m}$ mesh sieve, and the sieving fraction captured on this sieve was discarded (no spores were found). To capture spores for the counting, three sieves were attached below the top sieve. These sieves had opening sizes of 250, 105 and $53 \mu \mathrm{m}$ from top to bottom (Wet Sieving and Decanting method, Gerdemann and Nicolson 1963). The spores captured on the gridded filter paper were counted under a dissecting microscope with 40x magnification.

Dehydrogenase activity was determined by using procedure as outlined by Casida et al., 1964. Acid and alkaline phosphatase activity was determined by following procedure as outlined by Tabatabai and Bremer, 1969.

The five plant samples were dried in oven at $65 \pm 1{ }^{\circ} \mathrm{C}$ for 48 hours and dry biomass yield of the crop was recorded. The oven dried plant samples were ground thoroughly by a Wiley mill. A representative ground plant sample $(1.0 \mathrm{~g})$ was taken for digestion. For predigestion in conical flasks (100 $\mathrm{mL}$ capacity) the plant samples was soaked overnight with $5 \mathrm{~mL}$ of concentrated $\mathrm{HNO}_{3}$ and finally digested in a di-acid mixture $(8 \mathrm{~mL})$ containing $\mathrm{HNO}_{3}$ and $\mathrm{HClO}_{4}$ acid $(9: 4)$ on an electric hot plate following the procedure described by Piper (1967). The digested material was cooled, dilut-

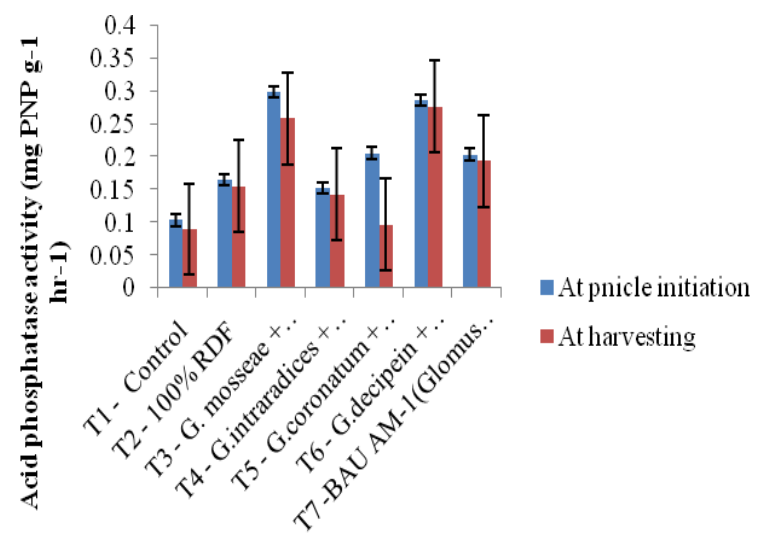

Treatment

Fig. 3. Effect of various AM fungi on acid phosphatase activity (mg PNP g $\mathrm{g}^{-1} \mathrm{hr}^{-1}$. ed with distilled water and filtered through Whatman No. 1 filter paper. The volume was made up to $100 \mathrm{~mL}$ and stored in a polypropylene container $(125 \mathrm{~mL}$ capacity) for further analysis. Total $\mathrm{Zn}$ content in the extract was determined by Atomic absorption Spectrophotomer (AAS). The same procedure has been used for the zinc content analysis in grain. Uptake of zinc by plant was calculated by following formula: $\mathrm{Zn}$ uptake by grain $\left(\mathrm{kg} \mathrm{ha}^{-1}\right)=$

$$
\frac{\text { Zn conc. in grain }(\%) \times \text { Grain y ield }\left(\text { pot }^{-1}\right)}{100}
$$

Analysis of variance (ANOVA) was performed as described by Gomez and Gomez (1984) to determine the effects of various treatments. Critical difference (CD) at $5 \%$ level of probability and $\mathrm{P}$ values was used to examine differences among treatment means.

\section{RESULTS AND DISCUSSION}

Root volume: The experimental results showed that the maximum root volume of rice was recorded at harvesting stage when compared with flowering stage (Fig. 1). The application of treatment $\mathrm{T}_{3}(G$. mosseae + $100 \%$ RDF NK) produced significantly more root volume by $72.60 \%, 17.80 \%, 12.25 \%, 14.13 \%$ over the application of treatment $\mathrm{T}_{1}$ (Control), treatment $\mathrm{T}_{5}$ (G.coronatum $+100 \% \mathrm{RDF} \mathrm{NK}), \mathrm{T}_{6}(G$. decipein + $100 \%$ RDF NK) and $\mathrm{T}_{7}$ (BAU AM-1 (G. $s p+100 \%$ RDF NK) respectively. Similar trend shows at harvesting stage, here the maximum root volume $(23 \mathrm{cc})$ was recorded by the application of $\mathrm{T}_{3}(G$. mosseae $+100 \%$ RDF NK). It might be due to the AM association besides facilitating nutrient uptake this also important in terms of root architecture as they are known to alter root topology (Schellenbaum et al., 1991). Positive effect on improvement of root volume by $G$. intraradices inoculation has been demonstrated in sesame (Boureima et al., 2008) and alteration in root length,

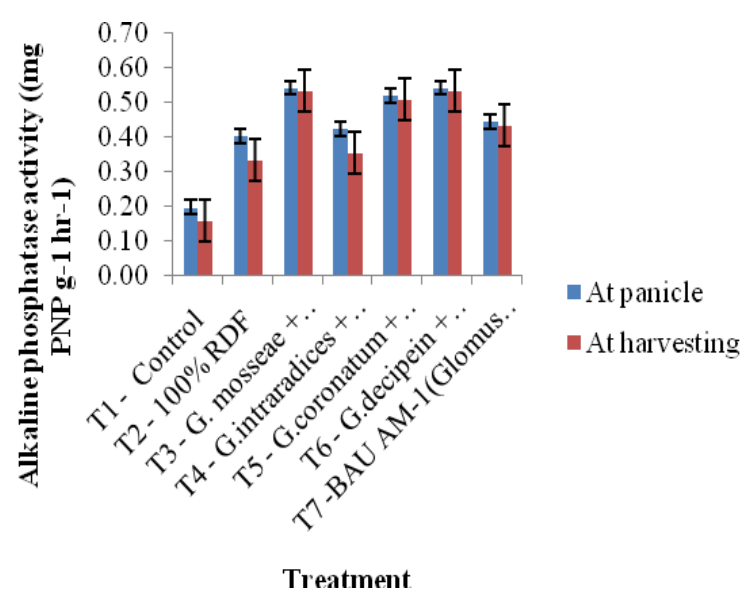

Fig. 4. Effect of various AM fungi on alkaline phosphatase activity $\left(m g\right.$ PNP $\left.\mathrm{g}^{-1} \mathrm{hr}^{-1}\right)$. 
Table 1. Effect of AM fungi and $\mathrm{N}$ and $\mathrm{K}$ on $\mathrm{AM}$ colonization (\%) at flowering and harvesting stage of DSR.

\begin{tabular}{|c|c|c|c|c|}
\hline \multirow[b]{2}{*}{ Treatment } & \multicolumn{2}{|c|}{ AM colonization $(\%)$} & \multicolumn{2}{|c|}{ Spore count (100 $\mathrm{g}^{-1}$ soil $)$} \\
\hline & Flowering stage & Harvesting stage & Flowering stage & $\begin{array}{c}\text { Harvesting } \\
\text { stage }\end{array}$ \\
\hline $\mathrm{T}_{1}-$ Control & 24.67 & 15.00 & 42.33 & 35.00 \\
\hline $\mathrm{T}_{2}-100 \% \mathrm{RDF}$ & 46.67 & 36.67 & 216.00 & 202.00 \\
\hline $\mathrm{T}_{3}-$ Glomus mosseae+ $100 \%$ RDFNK & 66.67 & 56.67 & 314.33 & 299.33 \\
\hline $\mathrm{T}_{4}-$ Glomus intraradices $+100 \% \mathrm{RDFNK}$ & 53.33 & 43.33 & 241.00 & 228.00 \\
\hline $\mathrm{T}_{5}-$ Glomus coronatum $+100 \% \mathrm{RDF} \mathrm{NK}$ & 56.67 & 46.67 & 301.67 & 286.33 \\
\hline $\mathrm{T}_{6}-$ Gigasporadecipein $+100 \% \mathrm{RDF}$ NK & 63.33 & 53.33 & 271.67 & 257.67 \\
\hline $\mathrm{T}_{7}-\mathrm{BAU}$ AM-1(Glomus sp. $)+100 \% \mathrm{RDF} \mathrm{NK}$ & 50.00 & 38.33 & 223.33 & 211.33 \\
\hline $\mathrm{CD}(0.05)$ & 14.60 & 12.50 & 5.46 & 6.56 \\
\hline $\mathrm{SE}(\mathrm{m})$ & 4.77 & 4.08 & 1.78 & 2.14 \\
\hline C.V. & 15.99 & 17.07 & 1.34 & 1.71 \\
\hline
\end{tabular}

surface area and volume as a result of mycorrhization has also been reported in Citrus and maize (Sheng et al., 2009; Wu et al., 2012).

AM colonization: The maximum AM root colonization was observed at flowering stage in comparison to the harvesting stage (Table 1). It might be due to the more infection of AM fungi with root of host plant and more release of plant photosynthate which is the carbon source to the AM fungi. The results are corroborating with the results of Singh and Kumar, 2007. At the harvesting stage application of treatment $\mathrm{T}_{3}(G$. mosseae $+100 \%$ RDF NK) produced significantly more $\mathrm{AM}$ colonization except treatment $\mathrm{T}_{4}(G$. intraradices $+100 \% \mathrm{RDF} \mathrm{NK}), \mathrm{T}_{5}(G$. coronatum +100 $\%$ RDF NK), and $\mathrm{T}_{6}(G$. decipien $+100 \% \mathrm{RDF} \mathrm{NK})$ by $62.99 \%, 29.99 \%$ and $25.03 \%$ than application of $\mathrm{T}_{1}$ (control) condition and $\mathrm{T}_{2}(100 \% \mathrm{RDF})$ and $\mathrm{T}_{7}$ (BAU AM -1(G. sp.) + $100 \%$ RDF NK), respectively. Similar trends was found at harvesting stage, hence it shows that the maximum AM colonization occur at flowering stage, which is inoculated with $\mathrm{T}_{3}(G$. mosseae $+100 \%$ RDF NK). It might be due to the mycorrhizal fungi differ in their ability to infect and colonize roots. Glomus species has ability to infect and colonize plant roots faster than Gigaspora species, making it highly competitive (Kurle and Pfleger, 1994). The higher mycorrhizal colonization in maize could be due to strigolactones exuded by host plant roots and taken up by AMF since strigolactones stimulate fungal metabolism and branching (Parniske, 2008). The role of strigolactones as the key signaling compounds in the interaction between plants and soilborne symbiotic AMF has been suggested recently (Soto et al., 2010).

Spore count: The data regarding spore count showed that the maximum spore counts were recorded at flowering stage in comparison to harvesting stage in all the given treatments (Table 1). The application of treatment $\mathrm{T}_{3}(G$. mosseae $+100 \%$ RDF NK) produced significantly higher spore count when compare with other applied treatments. It might be due to the more secretions of signal for root infection which are secreted by the host root, and more availability of plant photosynthate from plant to the associated fungi. The sim- ilar results were recorded by the Singh, et al., 2015 who found that the inoculation of $G$. mosseae produced maximum spore count when compared with other treatments at 75 DAS of maize in a pot experiment. The application of treatment $\mathrm{T}_{3}(G$. mosseae $+100 \% \mathrm{RDF}$ NK) produced significantly more spore count when compare with other applied treatments. This treatment also gave significantly more spore count than other inoculated application at harvesting stage. The maximum spore count (314.33 per $100 \mathrm{~g}$, soil) found at flowering stage under the treatment $\mathrm{T}_{3}(G$. mosseae + $100 \%$ RDF NK). It might be due to the mycorrhizal fungi differ in their ability to infect and colonize roots. Glomus species has ability to infect and colonize plant roots faster than Gigaspora species, making it highly competitive (Singh et al., 2015).

Soil enzymatic activity: The data on dehydrogenase activity is affected by various treatments at the panicle initiation and harvesting stage of rice which are presented in the results (Fig. 2). Microbial respiration is supposed to be highest in panicle initiation stage over harvesting stage of rice plant. This finding might be explained in the light of the report made by (Zeng Lusheng et al., 2005). In the present result at flowering stage, inoculation with $\mathrm{T}_{3}(G$. mosseae $+100 \% \mathrm{RDF}$ $\mathrm{NK}$ ) having given significantly higher dehydrogenase activity by $46.16 \%, 19.72 \%, 19.39 \%, 17.33 \%, 11.70$ $\%, 29.58 \%$ over treatments $\mathrm{T}_{1}$ (control) condition, $\mathrm{T}_{2}$ $(100 \% \mathrm{RDF}), \mathrm{T}_{4}(G$. intraradices $+100 \% \mathrm{RDF} \mathrm{NK})$, $\mathrm{T}_{5}(G$. coronatum $+100 \% \mathrm{RDF} \mathrm{NK}), \mathrm{T}_{6}$ (G.decipein $+100 \%$ RDF NK) and $\mathrm{T}_{7}$ (BAU AM -1 (Glomus sp.) $+100 \%$ RDF NK) respectively. It might be due to the mycorrhizal fungi can increases soil enzymatic activities, such as phosphatase (Mar Vazquez et al., 2000), dehydrogenase, urease, protease and $\beta$-glucosidase (Caravaca et al., 2003 and 2004).

The similar trend was observed for the acid phosphatase enzyme during the study. The inoculation with $\mathrm{T}_{3}$ (G. mosseae $+100 \%$ RDF NK) having more significantly acid phosphatase activity with respect to other inoculated species of VAM fungi (Fig. 3). Similar trends follow at harvesting stage, but in this stage inoculation with $\mathrm{T}_{3}(G$. mosseae $+100 \%$ RDF NK) having significantly more acid phosphatase activity except 
Table 2. Effect of Glomus mosseae, Glomus coronatum, Glomus intraradices, Gigasporadecipien on available $\mathrm{P}\left(\mathrm{kg} \mathrm{ha}^{-1}\right)$, DTPA, $\mathrm{Zn}\left(\mathrm{mg} \mathrm{kg}^{-1}\right.$ soil) $\mathrm{Zn}$ content and uptake by grain of rice.

\begin{tabular}{|c|c|c|c|c|c|}
\hline Treatment & $\begin{array}{c}\begin{array}{c}\text { Available P } \\
\left(\mathrm{mg} \mathrm{kg}^{-1}\right. \\
\text { soil })\end{array} \\
\end{array}$ & 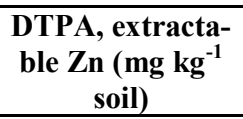 & $\begin{array}{c}\text { Zn content } \\
\text { in grain } \\
(\%) \\
\end{array}$ & $\begin{array}{c}\text { Zn uptake } \\
\left(\mathrm{g} \mathrm{pot}^{-1}\right) \text { by } \\
\text { grain } \\
\end{array}$ & $\begin{array}{c}\text { Grain } \\
\text { yield }\end{array}$ \\
\hline $\mathrm{T}_{1}-$ Control & 5.24 & 0.49 & 0.0024 & 0.019 & 7.77 \\
\hline $\mathrm{T}_{2}-100 \% \mathrm{RDF}$ & 6.27 & 0.50 & 0.0028 & 0.040 & 14.09 \\
\hline $\mathrm{T}_{3}-$ Glomus mosseae $+100 \%$ RDFNK & 7.40 & 0.52 & 0.0040 & 0.056 & 14.08 \\
\hline $\mathrm{T}_{4}-$ Glomus intraradices $+100 \%$ RDFNK & 6.77 & 0.48 & 0.0033 & 0.040 & 12.00 \\
\hline $\mathrm{T}_{5}-$ Glomus coronatum + $100 \% \mathrm{RDF} \mathrm{NK}$ & 6.91 & 0.51 & 0.0033 & 0.042 & 12.87 \\
\hline $\mathrm{T}_{6}-$ Gigasporadecipein $+100 \% \mathrm{RDF}$ NK & 7.07 & 0.50 & 0.0034 & 0.044 & 12.92 \\
\hline $\mathrm{T}_{7}-\mathrm{BAU}$ AM-1(Glomus sp. $)+100 \%$ RDF NK & 5.59 & 0.51 & 0.0033 & 0.036 & 10.99 \\
\hline $\mathrm{CD}(0.05)$ & 0.22 & 0.01 & 0.001 & 0.009 & 0.97 \\
\hline $\mathrm{SE}(\mathrm{m})$ & 0.10 & 0.07 & 0.0002 & 0.004 & 0.45 \\
\hline C.V. & 0.16 & 16.52 & 1.65 & 1.870 & 4.58 \\
\hline
\end{tabular}

$\mathrm{T}_{6}(G$. decipein $+100 \% \mathrm{RDF} \mathrm{NK})$, while the numerical value with the inoculation of $G$. mosseae is 0.28 $\mathrm{mg} \mathrm{PNPgm}{ }^{-1} \mathrm{hr}^{-1}$ and G.decipein having $0.26 \mathrm{mg}$ $\mathrm{PNPgm}^{-1} \mathrm{hr}^{-1}$. This finding has been well supported by the experimentation, undertaken by Mar Vazquez et al. (2000) who reported that the mycorrhizal colonization induced qualitative changes in the microbial population and enzyme activities in the rhizosphere of maize plants.

The application with the treatment $\mathrm{T}_{3}(G$. mosseae + $100 \%$ RDF NK) and treatment $\mathrm{T}_{6}$ (G.decipein +100 $\%$ RDF NK) given maximum Alkaline phosphatase activity at both the growth stages (Fig.4). The results for alkaline phosphatase activity by the application of G. mosseaeare the confirmation of Singh et al., 2015. The major contribution of soil enzyme pool is mainly mediated by soil microorganisms. In addition to that other soil microflora, plant residues undergoing varying degree of decay also contributed to this pool (Krishna et al., 2005). Alkaline phosphatase activity of soil increased up to panicle initiation stage afterwards it declined. Rice crop produced higher amount of root exudation in initial stages of growth which enhanced microbial activity in crop and modify nutrient concentration in soil (Dotaniya et al., 2014 and Singh et al., 2015).

Available phosphorous (mg kg-1) in soil after harvest: The presented data (Table 2) showed that addition of AM inoculation increased soil $\mathrm{P}$ concentration which was significantly higher over control. The application with the treatment $\mathrm{T}_{3}$ (G. mosseae $+100 \% \mathrm{RDF}$ $\mathrm{NK}$ ) given significantly more availability of phosphorus by $10.42 \%, 4.37 \%, 2.43 \%, 1.06 \%$ and $8.52 \%$ than treatment $\mathrm{T}_{1}$ (control) condition, $\mathrm{T}_{2}(100 \% \mathrm{RDF})$, $\mathrm{T}_{4}(G$. intraradices $+100 \% \mathrm{RDF} \mathrm{NK}), \mathrm{T}_{5}(G$. coronatum $+100 \%$ RDF NK) and $\mathrm{T}_{7}$ (BAU AM -1 (Glomus $s p).+100 \%$ RDF NK), respectively. It may be due to the Glomus mosseae had pronounced effect for phosphorus acquisition in soil. A parallel trend was also seen in case of available N, K and organic carbon status of alluvial soil (Olsson et al., 2010; Beura et al., 2016).
DTPA extractable zinc $\left(\mathrm{mg} \mathrm{kg}^{-1}\right)$ in soil after harvest: The perusal data (Table 2) stated that application with treatment $\mathrm{T}_{3}$ (Glomus mosseae $+100 \%$ RDF NK) increased significant DTPA extractable zinc by $5.76 \%, 3.84 \%, 7.69 \%$ and $3.84 \%$ than $\mathrm{T}_{1}$ (control) condition, $\mathrm{T}_{2}(100 \% \mathrm{RDF})$, inoculation with $\mathrm{T}_{4}(G$. intraradices $+100 \% \mathrm{RDF} \mathrm{NK})$ and $\mathrm{T}_{6}(G$. decipein $100 \%$ RDF NK), respectively. It might be due to the application of arbuscular mycorrhizal fungi increase the solubilization of unavailable zinc through their mechanism of acidulation. Higher root biomass mediated exudation and this was perhaps the most important reason for the increase. This result was in consonance with the findings of Habasy et al. (2005); Archana et al. (2012); Balakrishnan and Subramanian (2012); and Beura et al. (2016).

Effect of AMF species on zinc uptake by grain: The data from the result revealed that the application of different arbuscular mycorrhizal fungi increased the zinc content and uptake by the plant and grain (Table 2). The application of treatment $\mathrm{T}_{3}$ (G. mosseae +100 $\%$ RDF NK) given significantly more uptake of Zinc content in grain by $66.07 \%, 28.57 \%, 28.57 \%, 25 \%$, $21.42 \%$ and $35.71 \%$ than $\mathrm{T}_{1}$ (control) condition, $\mathrm{T}_{2}$ $(100 \% \mathrm{RDF})$ and inoculation with $\mathrm{T}_{4}(G$. intraradices $+100 \% \mathrm{RDF} \mathrm{NK}), \mathrm{T}_{5}(G$. coronatum $+100 \% \mathrm{RDF}$ $\mathrm{NK}), \mathrm{T}_{6}(G$. decipein $+100 \% \mathrm{RDF} \mathrm{NK})$ and $\mathrm{T}_{7}(\mathrm{BAU}$ AM -1 (G. sp.) + $100 \%$ RDF NK), respectively. It might be due to the more availability of zinc in the rhizosphere and absorption of more zinc from the beyond of depletion zone. AM fungi aid in going beyond this depletion zone to reach a new pool of soluble phosphate and some micronutrients (Marschner, 1995; Smith, 1997) via its extra-radical mycelial network extending the absorbing area (Johanson et al., 1993, Li et al., 1991) for increased P uptake and zinc According to Burkert and Robson (1994), arbuscular mycorrhizae can acquire $\mathrm{Zn}$ from a distance of $40 \mathrm{~mm}$ from the root surface. Jansaet al. (2003) noted that $G$. intraradices can take up $\mathrm{Zn}$ from a distance of $50 \mathrm{~mm}$ from the roots of maize.

Effect of AMF species on yield: The yield of direct 
seeded rice increased significantly over control with the inoculation of AM species (Table 2). Studies conducted by Sabia et al. (2015) also revealed a significant effect of AM inoculation on dry matter yield and quality of forage maize cultivated within a low input system. This might be due to enhanced nutrient uptake by the roots. Since, immobile ions in soil like phosphate lead to formation of a zone of phosphate depletion around roots in phosphate deficient soils mycorrhizal growth helps the roots to absorb phosphate ions much faster which are replenished at the root surface by diffusion. The inoculation with treatment $\mathrm{T}_{3}(G$. mosseae $+100 \%$ RDF NK) significantly increased grain yield by $44.81 \%, 14.77 \%, 8.59 \%, 8.23 \%$ and $21.94 \%$ than $\mathrm{T}_{1}$ (control) condition and inoculation with $\mathrm{T}_{4}(G$. intraradices $+100 \% \mathrm{RDF} \mathrm{NK}), \mathrm{T}_{5}(G$. coronatum $+100 \% \mathrm{RDF} \mathrm{NK}), \mathrm{T}_{6}(G$. decipien +100 $\%$ RDF NK) and $\mathrm{T}_{7}$ (BAU AM -1 (Glomus sp.) +100 $\%$ RDF NK), respectively. It might be due to the AM hyphae attached to the roots extend beyond this depletion zone and promote nutrient translocation from the soil to the plants through the root cortex. Studies conducted by Sabia et al. (2015) also revealed a significant effect of AM inoculation on dry matter yield and quality of forage maize cultivated within a low input system. Singh et al., 2015 also conducted a pot experiment for screening the AM fungi species for maize crop and found that with the application of $G$. mosseae the grain yield was found maximum (64.66 g plant $\left.{ }^{-1}\right)$.

\section{Conclusion}

The inoculation with AM fungus enhanced the soil dehydrogenase, acid phosphatase and alkaline phosphatase activities as compared to the control and application of $100 \%$ RDF. It also contributed to relative better plant growth and higher uptake of zinc by grain and shoot. As evident from the results, the AM fungal inoculation can effectively modify the soil microbe population and community structure by increasing the soil enzymatic activities and enhanced the zinc uptake by grain (0.036-0.056 $\left.\mathrm{g} \mathrm{pot}^{-1}\right)$ of DSR.

\section{ACKNOWLEDGEMENTS}

This research was carried out at Bihar Agricultural University, Sabour, Bhagalpur, Bihar, India, as M. Sc. (Ag) Soil Science and Agricultural Chemistry, research work. We hereby acknowledge the Department of Soil Science \& Agricultural Chemistry, BAU, Sabour for all the financial and technical assistance provided for this study.

\section{REFERENCES}

Archana, J., Amanullah, M. M., Manoharan, S. and Subramanian, K. S. (2012). Influence of iron and arbuscular mycorrhiza inoculation on growth and yield of hybrid maize in calcareous soil. Madras. Agric. J., 99: 65-67

Balakrishnan, N.. and Subramanian, K. S. (2012). Mycorrhi- zal symbiosis and bioavailability of micronutrients in maize grain. Maydica. 57: 129-138

Beura, K., Singh, M., Kumar, A., Rakshit, R. and Lal, M. (2016). Evaluation of Arbuscular Mycorrhiza Fungi Species for Their Efficiency Towards Nutrient Acquisition in Rhizospheric Soil of Maize. International Journal of Bio-resource and Stress Management, 7(1): 130135

Boureima, S., Diouf, M., Diop, T. A., Diatta., Leye, E. M., Ndiaye, F. and Seck, D. (2008). Effects of arbuscular mycorrhizal inoculation on the growth and the development of sesame (SesamumindicumL.). African J. Agri. Research, 3(3): 234-238

Burkert, B. and Robson, A. (1994). Zn uptake in subterranean clover (TrifoliumsubterraneumL.) by three vesiculararbuscular mycorrhizal fungi in a root-free sandy soil. Soil Biol. Biochem., 26:1117-1124

Busto, M. D. and Perez-Mateos, M. (1997). Stabilisation of cellulases by cross-linking with glutaraldehyde and soil humates Extraction of humic-fl-glucosidase fractions from soil. Biores Technol., 60: 27-33

Cakmak, I. (2008). Enrichment of cereal grains with zinc: agronomic or genetic biofortification. Plant Soil, 302 (12): $1-17$.

Caravaca, F., Alguacil, M. M., Azcon, R., Diaz, G. and Roldan, A. (2004). Comparing the effectiveness of mycorrhizal inoculation and amendment with sugar beet, rock phosphate and Aspergillus niger to enhance field performance of the leguminous shrub DorycniumpentaphyllumL. Appl. Soil Ecol., 25(2): 169-180

Caravaca, M. M., Alguacil, R., Figueroa, D., Barea, J. M. and Roldan, A. (2003). Re-establishment of Retamasphaerocarpaas a target species for reclamation of soil physical and biological properties in a semi-arid Mediterranean area. For. Ecol. Manage. 182: 49-58

Casida, L. E., Klein, D. A. and Santoro, T. (1964). Soil dehydrogenase activity. Soil Sci., 98: 371-376

Dotaniya. M. L. .Kushawah S. K., Rajendra, S. M. V. Coumar. (2014). Rhizosphere effect of kharif crop on phosphatases and Dehydrogenase Activities in a Typic Haplustert, Natl.Sci.Lett., 37(2): 103-106

Gao, X. P., Kuyper, T. W., Zou, C. Q., Zhang, F. S. and Hoffland, E. (2007). Mycorrhizal responsiveness of aerobic rice genotypes negatively correlated with their zinc uptake when Nonmycorrhizal. Plant Soil, 290:283291

Gerdemann, J. W. and Nicolson, T. H. (1963). Spores of mycorrhizal Endogone species extracted from soil by wet-sieving and decanting. Trans. Br. Mycol. Soc., 46: 235-244

Gomez, K. A. and Gomez, A. A. (1984) Statistical Procedures in Agricultural Research, By New York, Chichester, etc.: Wiley 2nd edition, paperback, Pp. 680

Habasy, N. R. and Abo-Zaid, M. M. A. (2005). Impact of Cd $-\mathrm{Pb}$ polluted water on growth and elemental composition of onion plants growth on a calcareous soil inoculated with mycorrhiza. Egypt. J. of Appl. Sci., 20: 586

Hajiboland , R., N. Aliasgharzad and Barzeghar, R. (2009). Influence of mycorrhizal fungi on uptake of $\mathrm{Zn}$ and $\mathrm{P}$ by two contrasting rice genotype s. Plant, Soil Environment, 55: 93-100

Harrington, J. T., Mexal, J. D. and Fisher, J. T. (1994). Volume displacement method provides a quick and accurate 
way to quantify new root production. Tree Planters' Notes, 45: 121-124

Jansa, J., Mozafar, A. and Frossard, E. (2003). Long distance transport of $\mathrm{P}$ and $\mathrm{Zn}$ through the hyphae of an arbuscular mycorrhizal fungus in symbiosis with maize. Agronomie, 23: 481-488

Johanson, A., Jakobsen, I. and Jensen, E. S. (1993). External hyphae of vesicular arbuscular mycorrhizal fungi associated with Trifolium subterranean L. III. Hyphal transport of $32 \mathrm{P}$ and $15 \mathrm{~N}$. New Phytologist, 7: 365-386

Krishna, H. K., Nagaraju, M. A. P. and, Kumar, H. C. (2005). Effect of conjugative micronutrients and bioinoculants on nodulation, quality and seed yield of soybean. Mysore J. Agric. Sci., 39(3): 374-378

Kurle, J.E. and Pfleger, F. L. (1994). The effect of cultural practices and pesticides on VAM fungi. In: F.L. Pfleger and R.G. Linderman (Eds.) Mycorrhizae and Plant Health. APS Press, Minnesota, Pp. 101-131

Lehman, A., Veresoglou, S. D., Leifheit, E. F and Rillig, M. C. (2014). Arbuscular mycorrhizal influence on zinc nutrition in crop plants - A meta-analysis. Soil Biol. Biochem., 69: 123-131

Mar Vazquez, M., Cesar, S., Azcon, R. and Barea, J. M. (2000). Interactions between arbuscular mycorrhizal fungi and other microbial inoculants (Azospirillum, Pseudomonas, Trichoderma) and their effects on microbial population and enzyme activities in the rhizosphere of maize plants. Appl. Soil Ecol., 15: 261-272

Marschner, H. Ed. (1995). Mineral nutrition of higher plants. Academic Press.

Olsson, Pal Axel., Rahm, Jannice. and Aliasgharzad, Nasser. (2010). Carbon dynamics inmycorrhizal symbioses is linked to carbon costs and phosphorus benefits FEMS Microbiol Ecol. 72: 123-131

Parniske, M. (2008). Arbuscular mycorrhiza: the mother of plant root endosymbioses, Nature Rev. Microb., 6:763775

Philips, J. M. and Hayman, D. S. (1970). Improved procedures for clearing roots and staining parasitic and vesicular-arbuscular mycorrhizal fungi for rapid assessment of infection. Trans Br Mycol Soc. 55: 158-161

Piper, C. S. (1967). Soil and plant analysis. University of Adelaide, Adelaide, Australia

Sabia, E., Claps, S., Morone, G., Bruno, A., Sepe, L. and Aleandri, R. (2015). Field inoculation of arbuscular mycorrhiza on maize (Zea mays L.) under low inputs: preliminary study on quantitative and qualitative aspects. Italian J. Agron., 10: 30-33

Schellenbaum, L., Berta, G., Ravolanirina, F., Tisserant, B., Gianinazzi, S., Gianinazzi-Pearson, V. and Fitter, A. H. (1991). Influence of endomycorrhizal infection on root morphology in a micropropagated woody plant species (VitisviniferaL.) Annals of Botany, 68: 135-141

Sheng, M., Tang, M., Chen, H., Yang, B., Zhang, F. and Huang Y. (2009). Influence of arbuscular mycorrhizae on root system of maize plants under salt stress. Can. J. Microbiology., 55(7): 879-886

Singh, M., Beura, K., Pradhan, A. K., Rakshit, R. and Lal, M. (2015). Ability of arbuscular mycorrhiza to promote growth of maize plant and enzymatic activity of an alluvial soil. J. App. and Nat. Sci., 7 (2): 1029-1035

Singh, M. and Kumar, N. (2007). Field evaluation of Bradyrhizobium, PSB and AM Fungus on Nodulation, Nutrient uptake, Growth and Yield of Soybean. Soybean Res., 5: 14-20

Smith, F. A. and Smith, S. E. (1997). Structural Diversity in (vesicular) arbuscular mycorrhizal symbiosis. New Phytologist, 137: 373-388

Soto, M. J., Fernaández-Aparicio, M., Castellanos-Morales, V., García-Garrido, J. M., Ocampo, J. A., Delgado, M. J. and Vierheilig, H. (2010). First indications for the involvement of trigolactoneson nodule formation in alfalfa (Medicago sativa). Soil Biol. Biochem., 42: 383385

Subramanian, K. S., Tenshia, V. Jayalakshmi, K. and Ramachandran, V. (2009). Role of arbuscular mycorrhizal fungus (Glomus intraradices) - (fungus aided) in zinc nutrition of maize. Journal of Agricultural Biotechnology and Sustainable Development, 1: 029-038

Tabatabai, M. A. and Bremner, J. M. (1969). Use of pnitrophenyl phosphate for assay of phosphatase activity. Soil Bio Biochem., 1: 301-307

Wu, Q. S., He, X. H., Zu, Y. N., Liu C. Y., Xiao, J. and Li, Y. (2012). Arbuscular mycorrhizas alter root system architecture of Citrus tangerine through regulatory metabolism if endogenous polyamines. Plant Growth Regulation, 68(1): 27-35

Zeng Lu-sheng, Liao Min, Chen Cheng-li and Huang Changyong. (2005). Variation of Soil Microbial Biomass and Enzyme Activities at Different Growth Stages of Rice (Oryza sativa), Rice Science, 12(4): 283-288 